\title{
A Function for the Plasmalemma Grooves of a Fission Yeast
}

\author{
By F. V. HEREWARD \\ Departments of Botany and Zoology, University of Manchester, Manchester $M_{13} 9 P L$
}

(Received 17 June 1976)

SUMMARY

Ultrastructural studies on regenerating protoplasts of Schizosaccharomyces pombe show that the spatial differentiation of the plasmalemma into grooves and flat areas is reflected in a functional differentiation in cell-wall synthesis. The grooves are the initial site of production of wall fibrils.

\section{INTRODUCTION}

The early development of routine methods for the preparation of yeast protoplasts and for the regeneration of their walls has lead to extensive studies of yeast wall synthesis. Electron microscopy using potassium permanganate fixation and shadow casting, autoradiography and chemical analyses are among the methods used (for review see Nečas, 1971), and techniques have been evolved for studying the independent synthesis of matrix and wall material (Nečas \& Svoboda, 1967; Nečas \& Kopecka, 1969). Such studies, together with biochemical and enzymological investigations (Behrens \& Cabib, 1968; Sentandreu \& Northcote, 1968) using whole cells, can lead to insight into the control of morphogenesis of the cell wall.

In higher plants there is a spatial separation of wall production; the synthesis of matrix materials occurs intracellularly, within the membrane system of the cell, whereas the synthesis of the cellulose fibrillar material is generally extracellular (Wooding, 1968). Enzymological studies on yeast have resulted in the localization of most of the enzymes involved in wall synthesis as intracellular (Keller \& Cabib, I97I; Ruiz-Herrera \& Sentandreu, 1975; Sentandreu, Elorza \& Villanueva, 1975). Work with higher plants (Northcote, 1974; Shore \& Maclachlan, 1975) has shown that the localization of enzymes is not a reliable guide to their sites of activity. Indeed, all enzymes must move by a definite route from the sites where they are synthesized to their sites of activity. Ultrastructural studies thus complement enzymological work.

The plasmalemma of yeast as revealed by freeze-etch studies (Moor \& Muhlethaler, 1963), in contrast to that of higher plants (Branton \& Moor, 1964; Northcote \& Lewis, 1968), shows localized differentiation: smooth areas, particle-covered areas and characteristic grooves (Ghosh, 1971) are seen. The cytoplasmic membrane system is less highly developed in yeast than in higher plants, and Golgi bodies have only rarely been reported (Havelkova, 1969; Kopecka, 1972).

Results reported in this paper show that there is a functional differentiation which parallels the structural differentiation of the plasmalemma of Schizosaccharomyces pombe. Using thin sections of glutaraldehyde-fixed protoplasts, the grooves in the plasmalemma have been identified as the sites at which the synthesis of wall fibrils is initiated. 


\section{METHODS}

Schizosaccharomyces pombe Lindner, $\mathrm{NCYCI} 32$ was grown in a medium containing $\mathrm{I} \cdot 3 \%$ (w/v) malt extract broth (Oxoid) supplemented with $0.7 \%(\mathrm{w} / \mathrm{v})$ mycological peptone (Oxoid). The inoculated medium was left at room temperature overnight and then shaken in an orbital incubator at $25{ }^{\circ} \mathrm{C}$ for about $2 \mathrm{~h}$, until a cell density of $5 \times 10^{6}$ cells ml $\mathrm{ml}^{-1}$ was attained. Protoplasts were prepared by the method of Mitchison (Mitchison, Creanor \& Satirama, 1973). They were pretreated for $0.5 \mathrm{~h}$ at $32{ }^{\circ} \mathrm{C}$ in a solution containing $0.4 \mathrm{M-2}-$ mercaptoethanol and 40 mM-ethylenediaminetetraacetic acid, and were then incubated for $0.5 \mathrm{~h}$ at $32{ }^{\circ} \mathrm{C}$ in $4 \mathrm{ml}$ of a solution containing Edinburgh Minimal Medium 2 (Mitchison, I970) with $1 \cdot 5 \mathrm{M}^{-\mathrm{MgSO}_{4}}$ and $30 \mathrm{~mm}-2$-mercaptoethanol, to which I $\mathrm{ml}$ of snail gut juice (Micro-Bio Laboratories, London) had been added.

Protoplasts were allowed to regenerate in the medium described by Nečas (1965) for I to $7 \mathrm{~h}$. They were then washed twice in buffered medium and fixed for $\mathrm{I} \mathrm{h}$ in a solution containing $4 \%(\mathrm{v} / \mathrm{v})$ glutaraldehyde buffered to $\mathrm{pH} 7$ with $0.08 \mathrm{M}$-phosphate, washed twice in buffer and postfixed in $\mathrm{I} \%(\mathrm{w} / \mathrm{v})$ osmium tetroxide buffered with veronal. The protoplasts were embedded in Araldite and thin sections were stained in a saturated solution of uranyl acetate in $50 \%$ aqueous ethanol at $60{ }^{\circ} \mathrm{C}$ for $20 \mathrm{~min}$, then washed and stained in alkaline lead citrate (Venable \& Coggeshall, 1965).

\section{RESULTS}

The protoplasts were well preserved by the fixation procedure used (Fig. I). The cytoplasm contained mitochondria, rough endoplasmic reticulum, vacuoles and fat bodies; smooth membrane was rare or absent. The protoplasts frequently appeared to be multinucleate. Observations on the dispositions of old walls in the medium (Fig. 4) suggested that protoplasts were released osmotically from weakened walls. Any wall material seen in the medium at this stage could be readily identified as old wall material by the compactness of the fibrils. Apart from these rare wall remnants (Fig. 4) cells were free of any wall material (Figs I, 2 and 3). The diameters of protoplasts were generally larger than those of the intact cells by a factor of between $I \cdot 2$ and 2 .

The plasmalemma remained intact and could be resolved into the two dark lines of the bilayer structure (Figs 2 and 3). The cell membrane stained asymmetrically (Fig. 2), the outer layer staining more intensely, sometimes in a globular or particulate manner (Fig. 3). Despite the increase in size of the protoplasts and their release by osmotic effects, depressions in the plasmalemma were still present (Figs 2 and 3).

Fig. I. A protoplast fixed shortly after the removal of the wall. No wall material is attached to the plasmalemma. Mitochondria, rough membrane and vacuoles can be seen. Bar marker represents I $\mu \mathrm{m}$.

Fig. 2. The invaginations in the plasmalemma of a protoplast. The membrane can be resolved into two lines. The more intense staining of the outer layer is not found where the invaginations occur. Bar marker represents $0.5 \mu \mathrm{m}$.

Fig. 3. The staining properties of the plasmalemma. The heavier staining of the outer layer of the plasmalemma can be resolved into a globular or particulate arrangement. The particles are not found in the invaginations. Bar marker represents $0.5 \mu \mathrm{m}$.

Fig. 4. Part of the old wall (OW) from which the protoplast has been released. The protoplast has developed a more extensively fibrillar network close to the old wall. Bar marker represents I $\mu \mathrm{m}$.

Fig. 5. The fibrils develop at or near invaginations and may have a forked or branched structure. The developing fibril (arrowed) has a very diffuse structure. Bar marker represents $0.5 \mu \mathrm{m}$. 


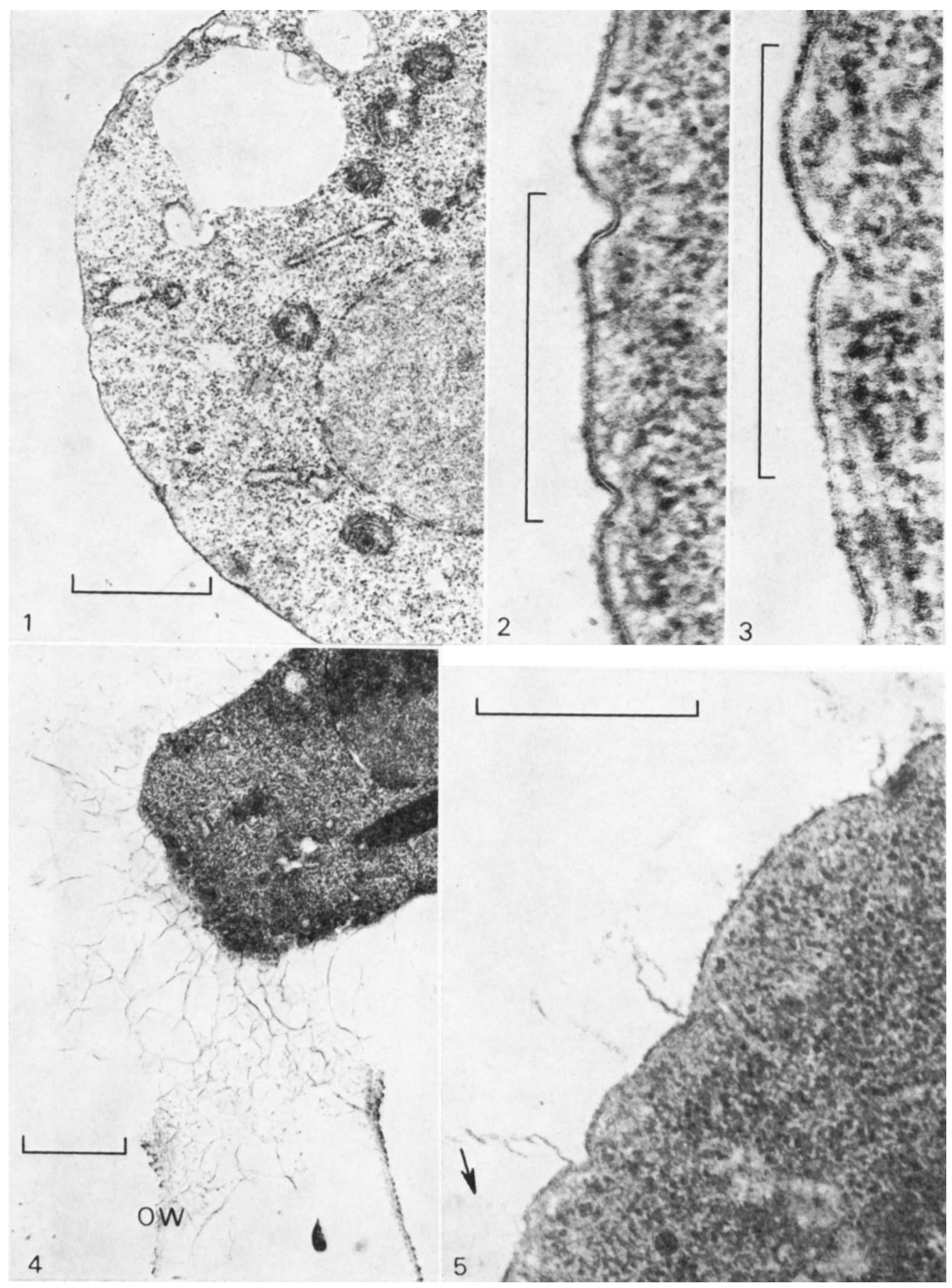



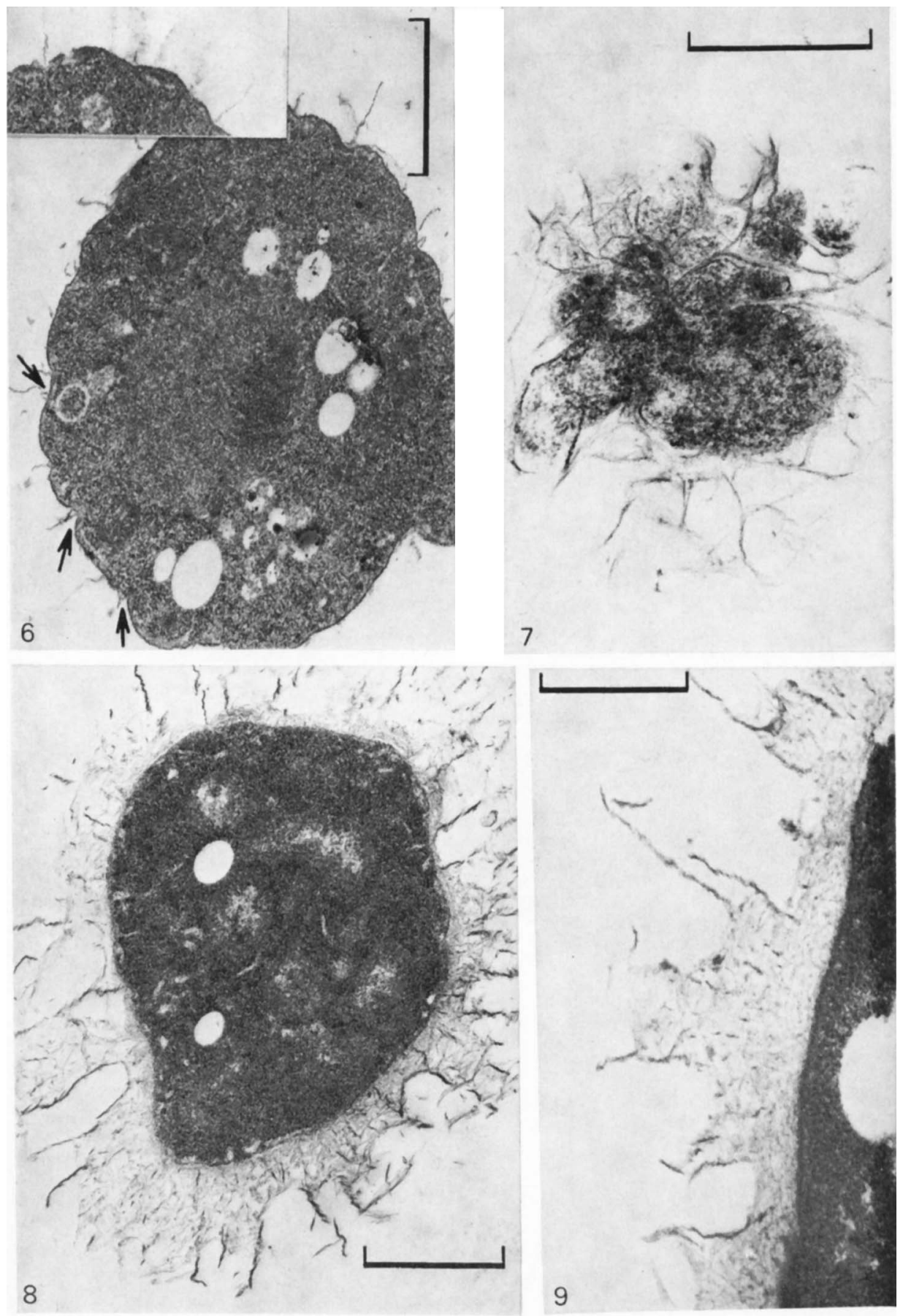
After $7 \mathrm{~h}$ in Nečas' (1965) medium, striking signs of wall regeneration were evident in some cells. The amount of wall formed was variable and Figs 5 and 6 show cells at very early stages. The first sign of wall development was the presence of fibrils radiating almost exclusively from the grooves or dips in the plasmalemma, some of which had widened out and appeared to be broader, shallower structures (Fig. 6). Glancing sections across the cell surface show the fibrils lying in the grooves (Fig. 7).

The fibrils were generally thick and clearly stained, but sometimes had diffusely staining zones (Fig. 5). There were no conspicuous changes in the cytoplasm which could be related to wall synthesis; no Golgi bodies were present, nor was there any proliferation of membranes or vesicles.

Fibril development occurred without a visible primer, although the proximity of old wall remnants resulted in more extensive synthesis (Fig. 4). At later stages of regeneration the fibrils developed fine side branches, visible as a fine haze (Fig. 6, inset), radiating at right angles (Figs 8 and 9). As the regenerating wall thickened, the fibrils which were synthesized first were pushed to the outside of the wall and the more recently synthesized wall nearer to the plasmalemma had a finer fibrous structure (Fig. 9). The fine material synthesized at later stages did not resemble the wall of intact cells but it was similar to the wall which remained after snail enzyme treatment (Fig. 4).

\section{DISCUSSION}

The control of wall synthesis in yeast is a suitable system in which to study the control of morphogenesis. For such a study it is necessary to correlate biochemical, ultrastructural and physiological observations. Schizosaccharomyces pombe is particularly suitable as extensive work has been done on its growth (Mitchison, 1963 ; Johnson \& Lu, 1975) and the control of the cell cycle (Nurse, 1975). Numerous studies have been made on the ultrastructure of regenerating protoplasts of this species (for example, Havelkova, 1969) but hitherto these have involved potassium permanganate fixation or shadowed or freeze-etched preparations, and no specific involvement of the membrane in wall formation has been observed.

The present study has been carried out on protoplasts in the early stages of regeneration, fixed with glutaraldehyde. The increase in size relative to intact cells was striking. After removal of the wall the cell volume is determined by the osmolarity of the medium. These yeast protoplasts can have up to twice the diameter of intact cells and the surface area may therefore expand by a factor of four. Such an increase in area of the membrane could be achieved either by stretching - although stretching on this scale is inconsistent with the fluid mosaic membrane model for membrane structure - or by the incorporation of membrane components from the cytoplasm. The lipid and hydrophobic protein constituents of membranes are in their lowest free energy state when they are incorporated into membranes;

Fig. 6. Fibrils originate from each invagination. Some fibrils (arrowed) appear to fork at their proximal end, thus a fibril may be made up of several components. Bar marker represents $\mathrm{I} \mu \mathrm{m}$. Inset shows fibrils developing a haze of side branches. Bar marker represents $0.73 \mu \mathrm{m}$.

Fig. 7. A glancing section through a regenerating protoplast. The developing fibrils can be seen in the invaginations. Bar marker represents $\mathrm{I} \mu \mathrm{m}$.

Fig. 8. A thick wall has developed. The thick fibrils synthesized at earlier stages are seen on the outer surface of the wall; the inner surface has finer and more extensively crosslinked fibrils. Bar marker represents $\mathrm{I} \mu \mathrm{m}$.

Fig. 9. The relationship between the thicker fibrils and the material synthesized at later stages can be seen. The finer fibrils appear to be supported between the coarse material produced initially. Bar marker represents $0.5 \mu \mathrm{m}$. 
thus if a significant increase in area of the plasmalemma occurs it is probably at the expense of intracellular membranes. This has important implications for the localization of enzyme activities which may be found in the plasmalemma of protoplasts as they may not be at their normal sites, although the plasmalemma did have a characteristic asymmetric structure.

The grooves in the plasmalemma of intact cells were also found in the protoplasts. Thus they had not opened out to contribute to the increase in surface area. The more intense, sometimes particulate, staining properties of the outer layer of the membrane did not extend into the grooves; this correlates with the freeze-etch observation of Streiblova (I968) that the particles found randomly distributed on the rest of the plasmalemma are not found in the grooves.

The first visible sign of wall synthesis was the formation of fibrils originating from the grooves. The glancing sections show a fibrillar net which strongly resembles that isolated from protoplasts and exposed by heavy-metal shadowing.

There are alternative explanations for the change in synthetic pattern from thick to finer fibrils. It is possible that the material was secreted from the whole surface during regeneration, but that without the coarse net synthesized from the grooves, it was lost into the medium. This is the situation in the regeneration of higher plant protoplasts: pectin is lost into the medium until the cellulose net has developed (Hanke \& Northcote, I974). However, this explanation does not account for the failure of protoplasts to synthesize the coarse fibres at later stages. An alternative explanation is that relatively simple polymers are secreted from specific points on the cell surface - the grooves - and that polymerization and crosslinking occurs to build up the final wall. In the initial stages of wall formation, the concentration of wall polymers or of a primer is only sufficient in the grooves, but the developing network, resulting from continued secretion, produces a high enough concentration and sufficient points of attachment to give the finer net seen at a later stage. This second suggestion is also supported by the observation that old walls in the regeneration medium result in more extensive wall formation where they are found close to regenerating cells. The coarse fibrils synthesized in the early stages do not resemble the normal wall of $S$. pombe but the finer fibrils do resemble the finer material found in wall remnants left after protoplast formation.

The wall of $S$. pombe is composed mainly of glucan (Kogane \& Yanagita, 1962; Bush et al., 1974); it contains very little mannan and no chitin. Kreger \& Kopecka (1973) have suggested that in regenerating Saccharomyces cerevisiae protoplasts the anomalous fibrillar nets result from the unbalanced synthesis of the glucan component. The fibrils are made up of $(\mathrm{I} \rightarrow 3)-\beta$ glucan which is normally a component of the side branches; there was no synthesis of the $(I \rightarrow 6)-\beta$ polymer which is the backbone of the normal wall glucan.

The association of the plasmalemma grooves with fibril synthesis shows that these areas of the plasmalemma have a specific, possibly secretory, function in relation to fibril production in protoplasts. The final stages of the polymerization of any complex three-dimensional network must be extracellular. However, most of the enzymes involved in wall synthesis have been localized as intracellular (mannan synthetase: Ruiz-Herrera \& Sentandreu, 1975; glucan synthetase: Sentandreu et al., 1975) and the only enzyme for which there is a definite localization in the plasmalemma is the chitin synthetase (Duran, Bowers \& Cabib, 1975). The universal presence of grooves in the plasmalemma of yeasts points to a common function, and it is generally thought that all walls require a matrix and a fibrillar component (Northcote, 1972). The work described here suggests that the grooves are the site of initiation of the fibrillar component.

I am grateful to Dr David Moore for his constructive reading of the manuscript. 


\section{REFERENCES}

BEHRENS, N. H. \& CABIB, E. (I968). The biosynthesis of mannan in Saccharomyces carlsbergensis. Journal of Biological Chemistry 243, 502-509.

BRaNTON, D. \& MoOR, H. (1964). Fine structure in freeze-etched Allium cepa L. root tips. Journal of Ultrastructural Research II, 40I-4II.

Bush, D. A., Horisberger, M., HoRman, I. \& Wursch, P. (1974). The wall structure of Schizosaccharomyces pombe. Journal of General Microbiology 81, 199-206.

Duran, A., Bowers, B. \& CABIB, E. (1975). Chitin yeast synthetase is attached to yeast plasmamembrane. Proceedings of the National Academy of Sciences of the United States of America 72, 3952-3955.

Grosh, B. K. (1971). Grooves in the plasmalemma of Saccharomyces cerevisiae, seen in glancing sections of double aldehyde fixed cells. Journal of Cell Biology 48, 192-197.

HANKE, D. E. \& NoRThCOTE, D. H. (1974). Cell wall formation by soybean callus protoplasts. Journal of Cell Science 14, 29-50.

HavelKova, M. (I969). Electron microscopy study of cell structures and their changes during growth and regeneration of Schizosaccharomyces pombe protoplasts. Folia Microbiologica (Praha) 14, I55-164.

JoHnson, B. F. \& LU, C. (1975). Morphometric analysis of yeast cells. IV. Increase in the cylindrical diameter of Schizosaccharomyces pombe during the cell cycle. Experimental Cell Research 95, I54-158.

Keller, F. A. \& CABIB, E. (I97I). Chitin and yeast budding. Properties of chitin synthetase from Saccharomyces carlsbergensis. Journal of Biological Chemistry 246, 160-166.

KogANE, K. \& YANAGITA, T. (1962). Qualitative and quantitative studies on the cell wall carbohydrate in the yeast Schizosaccharomyces pombe. Chemical and Pharmaceutical Bulletin (Tokyo) ro, 6I-66.

KopeCKA, M. (1972). Dictyosomes in the yeast Schizosaccharomyces pombe. Antonie van Leeuwenhoek $3^{8}$, 27-3I.

KREGER, D. R. \& KoPECKA, M. (I973). On the nature of the fibrillar nets formed by protoplasts of Saccharomyces cerevisiae in liquid media. In Yeast, Mould and Plant Protoplasts, pp. I17-130. Edited by J. R. Villanueva, L. García Acha, S. Gascón and F. Uruburu. London: Academic Press.

Mrtchison, J. M. (1963). Pattern of synthesis of RNA and other cell components during the cell cycle of Schizosaccharomyces pombe. Journal of Cellular and Comparative Physiology 62 (Suppl. I), I-13.

Mrtchison, J. M. (1970). Physiological and cytological methods for Schizosaccharomyces pombe. In Methods in Cell Biology, vol. 4, pp. 13I-165. Edited by D. M. Prescott. London: Academic Press.

Mitchison, J. M., Creanor, J. \& Satirama, M. L. (1973). Enzyme synthesis, RNA synthesis and effect of actinomycin in the fission yeast. Schizosaccharomyces pombe. In Yeast, Mould and Plant Protoplasts, pp. 229-245. Edited by J. R. Villanueva, L. García Acha, S. Gascón and F. Uruburu. London: Academic Press.

MOOR, H. \& Mühethaler, K. (1963). Fine structure in frozen-etched yeast cells. Journal of Cell Biology 17 , 609-628.

NEČAS, O. (1965). Mechanism of regeneration of yeast protoplasts. III. Electron microscopy of growing protoplasts. Folia biologica (Praha) Ir, 371-377.

NEČAS, O. (1971). Cell wall synthesis in yeast protoplasts. Bacteriological Reviews 35, 149-170.

NeČAs, O. \& KoPECKA, M. (1969). Synthesis of the fibrillar component of regenerating cell walls in yeast protoplasts. Antonie van Leeuwenhoek 35, Suppl. B6-B8.

NeČAS, O. \& SvoBodA, A. (1967). Relation between the biosynthesis of the cell wall and regeneration in yeast protoplasts. In Symposium über Hefe-Protoplasten, pp. 67-7I. Edited by R. Muller. Berlin: Akademie Verlag.

NoRthCOTE, D. H. (1972). Chemistry of the plant cell wall. Annual Review of Plant Physiology 23, I I3-I 32.

Northcote, D. H. (1974). Complex envelope system. Membrane systems of plant cells. Philosophical Transactions of the Royal Society 268, $119-128$.

NorthCote, D. H. \& Lewis, D. R. (1968). Freeze-etched surfaces of membranes and organelles in the cells of pea root tips. Journal of Cell Science 3, 199-206.

NuRSE, P. (1975). Genetic control of cell size at cell division in yeast. Nature, London 256, 547-55I.

RuIZ-HerrerA, J. \& SENTANDREu, R. (1975). Site of initial glycosylation of mannoproteins from Saccharomyces cerevisiae. Journal of Bacteriology 124, $127-133$.

Sentandreu, R. \& Northcote, D. H. (I968). The structure of a glycopeptide isolated from the yeast cell wall. Biochemical Journal 109, 419-432.

Sentandreu, R., Elorza, M. V. \& Villanueva, J. R. (I975). Synthesis of yeast wall glucan. Journal of General Microbiology 90, 13-20.

Shore, G. \& MAClACHLAN, G. A. (1975). The site of cellulose synthesis. Journal of Cell Biology 64, 557-57 r.

STrEIBLOVA, E. (1968). Surface structure of yeast protoplasts. Journal of Bacteriology 95, 700-707.

Venable, J. H. \& Coggeshall, R. (I965). A simplified lead citrate stain for use in electron microscopy. Journal of Cell Biology 25, 407-408.

WoodnNG, F. B. P. (1968). Radioautographic and chemical studies of incorporation into sycamore vascular tissue walls. Journal of Cell Science 3, 71-80. 